\title{
Gender Crisis in Poland, Catholic Ideology and the Media
}

\author{
Anna Odrowąż-Coates \\ The M. Grzegorzewska Academy of Special Education, Warsaw, Poland \\ Email: acoates@aps.edu.pl
}

Received 3 November 2014; revised 10 December 2014; accepted 22 December 2014

Copyright (C) 2015 by author and Scientific Research Publishing Inc.

This work is licensed under the Creative Commons Attribution International License (CC BY). http://creativecommons.org/licenses/by/4.0/

(c) (i) Open Access

\begin{abstract}
The author discusses the "anti-gender" debate initiated by the Catholic Church in Poland, which has proclaimed a deepening crisis of family and society and has accused gender ideology of being responsible. At the end of 2013 , a campaign emerged within the Church to undermine gender theories and to put blame on gender theorists for societal flaws. The discourse has been elaborated on in the media and has created an atmosphere of friction and unrest between academics involved in gender studies and church representatives. The nation has been divided in its understanding and acceptance of gender, with people heavily influenced by sermons in local churches and by the Catholic press. This paper contains a critical analysis of the Church's stand point on gender issues in Poland and the results of a survey of public opinion carried out by the author. Denial and rejection of gender theories by the Polish Catholic Church should not be ignored. This denial may have a negative impact on women's rights and their position in Polish society and undermine the work of multiple generations of researchers, suffragettes and feminists. Moreover it is highly offensive to diverse communities and therefore should be highlighted and addressed in the wider context. The article should be treated as a viewpoint based on media discourse analysis and a small scale empirical research, based on interpretative paradigm.
\end{abstract}

\section{Keywords}

Gender, Gender Studies, Gender Ideology, Prejudice, Sociology of Religion

\section{Introduction}

Gender may be defined as a socially constructed feminine or masculine identity of an individual, enforced through socialization processes, which becomes a basis of social division and a set of everyday social practices. The distinction between "sex" and "gender" was first made in 1965 in the work of John Money. It was then further 
theorized by Robert Stoller (1968) and developed by Ann Oakley (1972) and many others (Connell, 1987; Laqueur, 1990; Fausto-Sterling, 1992, 2000). In early usage, the study of "gender" was the study of women, sex roles or both (Acker, 1992). However, in the last few decades "gender" has become a part of the everyday language of social science. Wendy C. Harrison poignantly said: the challenge for feminism is to produce a social science that recognizes and understands the biological, without taking biological characteristics as a given, ... because human beings are pre-eminently social and cultural creatures who, in shaping the world around them, also shape themselves (Harrison, 2006). Taking inspiration from Simone de Beauvoir (1949, 1972: p. 14) feminism must face the fact that the difference between the sexes is the most fundamental of human differences, which may have implications in the way men and women are treated and in their choices. The imperative role of Gender studies is to explore how these choices may be limited and reveal if there is any social injustice or social gap in gender-based life opportunities. To open the debate, it has to be said that a scientific discussion on gender is ongoing and is so far inconclusive. Some, like Judith Butler (1993), question the materiality of "sex" against the lack of physical embodiment of "gender". The human body, in her view became something outside and beyond minds, relationships and language, making "sex" a given, irreducible feature, beyond human thought. Kessler's and McKenna's (1878: p. 6) research showed that once people decide what is one's gender they interpret everything this person does in the light of their gender affiliation. It is worth noting that this gives people “cultural genitals (Kessler, 1998: p. 86)", collapsing sex and gender into one.

A question emerges, is there such a thing as "gender ideology"? The Polish Roman Catholic (RC) Church says there is. Judith Lorber defines "gender ideology" as "the justification of gender statuses, particularly their differential evaluation. The dominant ideology tends to suppress criticism by making these evaluations seem natural (Lorber, 1994: p. 30)" Looking at Lober's definition one may wonder if this is what the Church had in mind?

In the following part of the paper, one may find a review of the discussion that has taken place in the public debate on gender, which was initiated by a letter read in all RC churches in Poland on 29 December 2013. From that point onwards "gender" became a widely discussed subject in the public sphere and at home. In the final section of this paper, a case study based on a small scale qualitative survey of general public opinion on 'gender' will be presented, followed by conclusions.

\section{Church and Media Discourse}

In online publications written in English one may find an article by Jonathan Luxmoore (2014), entitled: "Polish Church declares war on gender ideology — A pastoral letter by Polish bishops has caused backlash from some who see attack as a witch hunt”. The full content of the letter can be found on the KAI website (Wiara.pl, 2014a). It is worth mentioning is that it was not obligatory to read the letter to parishioners, however, this is what happened (Polskie Radio, 2014). The letter claimed that there is a gender ideology, which is based on Marxism and neo-Marxism which leads to experiments on children and endangers society in many ways. They condemned gender ideology as responsible for low birth rates, the collapse of traditional family models, the breakdown of marriages, abortion, homosexuality, sexual freedom due to contraception, the early sexualisation of children and many other (in their view), negative phenomenon that are a threat to family, society and the whole of humanity. The letter was a reaction to Pope Benedict's XVI Christmas address from 2012, when the Pope declared that gender theory is a new philosophy of sexuality, where sex is a social role one chooses for oneself and is not bestowed by nature. There were multiple individual responses by bishops in Poland. The first one came from the General Secretary of the Polish Episcopal Conference, Bishop Wojciech Polak. The faith community portal wiara.pl, quotes an interview with the bishop, who states that gender ideology is a danger for a family and therefore for the whole of society. He thinks that gender redefines people's identity and people's humanity (Wiara.pl, 2014b). Earlier on, in October 2013, the head of the Church's Catholic Education Commission, Bishop Marek Mendyk, demanded removal of gender ideology from Polish education. Soon after, Bishop Kazimierz Ryczan urged Polish parliament members to "defend the homeland against totalitarian genderism". Archbishop Marek Jedraszewski warned Lodz parishioners that "gender” would bring the "denial of God and "death of civilization (Luxmoore, 2014)". Archbishop Henryk Hoser said that "gender” is a "denial of God's creation and is a big anthropological lie" (Polskie Radio, 2014). He said that according to gender ideology, one may flexibly choose their gender and gender is treated as a changeable and negotiable social role and not a given biological feature. At the beginning of the media debate, the RC church displayed a level of openness inviting a number of gender specialists for a debate in the Episcopal secretariat in Warsaw. During the conference Dr Leszek 
Woroniecki, a priest, demonstrated that not only Poland but many other European countries initiated the gender debate (Wpolityce.pl, 2014). He referred to a Spanish document of 2012 "The truth of human love" (Mantovani, 2013), where Spanish bishops show that gender ideology lead to death not to life. Costa Rican, Slovakian and Swiss bishops followed their footsteps in letters of a similar tone. Conference participants referred to Bishop Chur Vitus Huonder who on the 10 December 2013 wrote that gender is a theory of a great lie. Dr Woroniecki also claimed that there is a successful opposition in France to stop gender (sic) from entering French schools. At the same conference, Malgorzata Fuszara, a renown gender specialist, said that gender is a form of a social perspective that does not deny one's sex/gender, on the contrary it goes beyond this socio-demographic statistic and it reveals the influence of sex/gender on people's life and opportunities (Ekai.pl, 2014). Meanwhile, the conference organizers claimed that they were not trying to defend the Church, but wished to save humans from gender ideology and its dangers. According to Fuszara, gender is not about an ideology, but about social and cultural identity based on sex (Newsweek Polska, 2014).

The gender debate in the media and society as a whole, accelerated in the following months (Youtube, 2014). Gender became a vivid topic of social interactions, fuelled by the media and by sermons in churches. There were also some "street” actions. In front of St. Mary’s Basilica in Cracow, Jan Hartman from “Twoj Ruch", the only political party in Poland that openly supports Gay, Lesbian, Transgender and bisexual (GLTB) people, read out loud a response letter, which contained an attack on the RC Church for paedophilia incidents, claiming that the "gender" agenda is a form of diffusion of responsibility and turns attention away from real problems. He claimed that Polish families have problems of poverty and unemployment, not one of "gender" (Polskie Radio, 2014).

There are significant differences between gender discourse in faith based newspapers and magazines and secular ones. At the catholic oriented internet information web portal Fronda.pl, one may find the article Gender and the Reproduction Rights, by Prof. Maria Ryś (2014), which says that academic websites have removed the information about women's reproduction rights that were there before, to cover up the true mission of gender studies, which exists, according to the author of the article, to gain societal approval for abortion, contraception and in-vitro. The author claims that the gender scientists re-named procreation, which is a human expression"the reproduction"-which is purely reserved for animals and plants. The author quotes the following study: Mark Regnerus (2012), How different are the adult children of parents who have same-sex relationships? Findings from the New Family Structures Study, that compared 40 social emotional and relational factors amongst children raised by heterosexual couples and those raised by homosexual couples. The outcome of the study demonstrated some negative impact of homosexual parents on the upbringing of their children.

The same author, Maria Ryś (2013), in the "Idziemy” magazine 50 (431), 15 December 2013 expressed the opinion that due to the popularity of gender agenda, sexual education at Polish schools, in its current form, denies the importance of chastity, fidelity and modesty, promoting harmful models of promiscuous and irresponsible sexual behaviour.

Archbishop Henryk Hoser, in an interview for a right wing daily paper "Nasz Dziennik", claims that promoting gender is a form of social engineering, which fights the positive stereotypes of the traditional family, which would normally give a good example to new generations. The promotion of gender according to Hoser, also gives women a false feeling of discrimination when carrying out "natural biological tasks" and turns the family structure into a structure of oppression for individuals, that one should rebel against (Jędrzejczyk, 2014).

In the article Gender and Paedophilia by Joanna Podgórska, published in December 2013, in the weekly magazine Polityka, the author claims that "gender" has become enemy number one in church-oriented public perception, to diffuse the attention of church goers from the paedophilia scandals within the RC church itself.

In January 2014, “Polityka” published another article On Children for Adults, that articulates parental worries caused by the gender debate, where parents are confused and alarmed by the Church's claims that gender politics lead to extremely early sexualisation of children causing them to become addicted to sexual practices, pornography, pharmaceutical and the erotic industry's products. The author quotes: Beata Kempa, a right wing politician, who compares gender issues to a "mafia" that spreads into Polish nurseries and schools. In a different interview for Newsweek Polska, Beata Kempa claims that gender is shaking the traditional order of the Polish family and also encourages children to choose their gender at four years old (Pawlicka, 2014). In the interview one may observe a lack of knowledge of what gender is and of what gender studies are by the interviewee, who now heads the newly established parliamentary group, named: "Stop the gender ideology". Beata Kempa has started a road campaign to raise awareness about the dangers of gender ideology. She wants to warn people that gender leads to dressing boys as girls and encouraging them to wear long hair wigs and play with female specific 
toys. She also said she is against adoption by homosexual couples (Bohdanowicz, 2014).

When asked about gender discussion, the Minister of Education and Tertiary Education, Lena KolarskaBobińska, defended the openness and independence of scientific research, enabling full freedom of scientific critique and development of social theories. She said that only such freedom will allow for unlimited development of thought on any social phenomenon (Gazeta Wyborcza, 2014). Professor Agnieszka Rothert, an expert on feminist and gender studies, from the Political Science Department of the University of Warsaw, said during an interview for Newsweek Polska, that in the past RC church authorities, who now portray gender as a make believe field of studies, thought of Galileo, Nicholas Copernicus and Giordano Bruno, as "pretend scientists" in the past (Rogojsz, 2014).

Archbishop Michalik was sued by Ms Marenin, who is a feminist, single mother and divorced. She felt deeply offended and stigmatised by the content of the archbishop's letter that stated: aggressive feminists and parents who decide to divorce are responsible for paedophilia. The court decided that Archbishop Michalik was allowed to speak his mind under the freedom of speech and that the generalisation used means one can not identify any particular victim of his sermon (Newsweek, 2014).

Bishop Tadeusz Pieronek said that RC church is promoting gender equality, but is against the "production" of children by "gender" and the replacing of mother and father with gender neutral parent number 1 and parent number 2. He also said that gender acts against God's order and the long-lasting relationships between people (Ibidem). Bishop Jozef Zawitowski thinks that gender is a cultural revolution leading to the removal of the words: mother and father in favour of parent and boy or girl in favour of child, and that this child will choose their gender at adulthood (Rzewuski, 2013).

At a meeting of the Parliamentary Committee Against the Atheisation of Poland, Fr Dariusz Oko spoke about gender ideology as "anti-Christian battering ram against the RC church" ... "which is written by atheists and by sexual maniacs” (Baliszewski, 2014).

Leftwing politicians support gender ideology. Leszek Miller, said that gender is about parity between men and women and as such his party supports gender agenda in public life (PAP, 2014).

Barbara Limanowska an activist and an advisor to the UN and the OSCE to prevent human trafficking, promote human rights and women rights, gave an extensive description on gender and how it is focused around matters of equity, diversity and tolerance (Tutak-Goll, 2013). Gender in her view is far from being an ideology, it is a humanistic theory of gender based relations of power and interactions in the society. She said that promoting awareness of gender is beneficial for attainment of parity and aids social cohesion.

The weekly catholic magazine, "Sunday", published an interview with Dale O'Leary, the author of The Gender Agenda: Redefining Equality, in which one may wonder if the questions were added post-factum (Redzioch, 2014). O'Leary claims that the feminist movements aim to bring up children without a family, to terrorize the world with their radical ideas, to accept homosexual parenthood, to change men into 'pseudo men' and to deny the natural differences of gender (Ibidem). In church-driven gender discourse, feminism is associated with secularism and the loss of religious values. In opposition to the Polish Roman Catholic Church view, many scientists claim that having a feminist outlook on life does not equate with the loss of religion and religious values. In fact, one may find that there is a strong notion of religious feminism in existence (see: Daggers, 2002; Ingersoll, 2003; McGinty, 2006, 2007, 2012; Zwissler, 2007; Aune et al., 2008; Badran, 2009; Klassen, 2009; Fedele, 2012; Fedele \& Knibbe, 2013).

Radio Talk FM, published an article entitled: Gender science versus the ideology of Jesus (Radomski, 2014), posing claims to a balanced view on the discussion between academics and Church authorities. It quoted an interview with Fr Alfred Wierzbicki, of the Catholic University of Lublin, who defended the concept of gender as cultural conditioning and claimed that Christianity should understand this concept, through conviction, that being human is not solely a biological existence, but something more.

On 14 January 2014, the Polish Ministry of Education and Tertiary Education took an official position on the matter of gender studies (Kolarska-Bobińska, 2014). The Ministry supported the freedom of scientific research, the freedom of science, existence and the historic roots of this discipline of studies. The Ministry referred to the EU program: Horizon 2020, which is aimed at improving equality, including gender parity. Individual institutes within the social science field felt obliged to respond and to explain what gender studies are, on their websites and in ad hoc seminars. For example, the Adam Mickiewicz University of Poznań has published an open letter to the Minister of equal opportunities, Agnieszka Kozłowska-Rajewicz, addressing areas of unjust claims that affected the image and good name of gender specialists. They condemned inter alia: the manipulation with the 
word gender, disclosing untrue information about it, ridiculing gender studies, being disrespectful of existing scientific research into the field and blaming gender studies for paedophilia. The authors of the letter felt intimidated and victimised and filed a complaint against recent RC Church actions (Kraskowska et al., 2013).

The online edition of KAI (Catholic information agency) stated that the gender discussion is fuelled by a growing worry about the implementation of EU regulations on gender equality, which will forbid discrimination based on sexual identity and sexual orientation, and in the view of the editors, limit freedom of speech. They are also worried about the outcomes of the Convention on the Prevention of Violence against women and Domestic Violence ratified in 2012, which will implement a new programme of education to fight gender stereotypes that are an effect of culture, tradition and religion, which in their view will have a negative impact on millions of young Poles (Petrowa-Wasilewicz \& Przeciszewski, 2013).

There have been "incidents" at nurseries that were taken out of context and portrayed as "gender ideology" at pre-school. For example, a boy dressed in a wig and skirt, putting make up on a teacher, to show other children the profession of a beautician, whilst children were discussing different types of paid occupations. It had no planned "gender" implication. However, a photograph documenting this event spread quickly on the Internet and local government representatives in Wrocław formed a working group headed by a local parish priest dr Marek Kluwak, to combat gender ideology at school and nursery. They said that they were alarmed by inappropriate teaching programmes that in their view promote sexual freedom and demoralise young people (Grzelinska, 2014).

Most recently a new initiative emerged, initiated and lead by Fr Ok-a three months course: "Gender-Hidden truth" based in Gliwice (Silesia region), directed at parents, teachers, students and activists, who in the course organizers view, want to protect their families. Fr Oko calls for a war against gender. He claims that course participants will be victorious, even if they become martyrs for the cause. He states that it is a "war for life and death", however it is a cultural not military conflict, a "war against manipulation" and "against putting homophobes in prisons" (Gumowska, 2014).

In the Polish national climate one may sense a notion of gender, portrayed as a hideous monster, hiding in children's closets. According to the RC church in Poland, this monster will clearly need to be expelled for the sake of the common good. The author of this article feels that if Poland truly wishes to bring genuine equality into its society, "Gender" must be demystified and properly defined in academic terms, which are somehow overlooked by the church, so that the general public can make informed choices. In the author's view the RC church in Poland uses Gender as a scapegoat and is in fear of changes in role models brought about by the feminist movement, as they lead to lower birth rates and a higher reflexivity of potential church goers. Instead of embracing these changes, modifying the approach to equality and incorporating the idea of human dignity for all, despite their gender, the Polish RC church feels threatened and fights back using demagogy and fear to keep its subjects compliant and scared of the unknown, misunderstood, potential dangers. This strategy is in the author's view, short-sighted and may lead to further divisions within Polish society.

\section{Confused Public-A Survey Study of Public Reaction}

From January 2014 until May 2014 the author carried out a number of informal discussions that may be classed as unstructured interviews on the subject of gender. Respondents were chosen at random, in opportune circumstances with a scope to include wide range of age groups and people with diverse socio-demographical features. 12 students in the first year of bachelors studies, 12 students in the final year of Master degree studies, 8 academics at PhD level and above, 7 residents of old people's home, 10 parents of preschoolers from a private nursery, 13 parents of second grade pupils from government founded comprehensive school, 4 pensioners and 3 priests. This small group can not be treated as representative of the Polish society in general, but should give a notion of the public's reaction to the church-media gender discourse. The majority of people where unsure what gender is and what gender studies are, the awareness was more accurate amongst academics and students in their final year, however some also felt a degree of uncertainty and worry about the direction the church-media discourse may take. They were concerned about the future of the gender discipline in Poland and embarrassed about the negative message this discussion sends abroad, affecting the image of the Polish nation. All the elderly interlocutors and the majority of people with no higher education, believed that the Church must be right and that the gender ideology, whatever it is, as they could not understand it, must be defeated by all means. They also did not realize the roots of gender studies that pertain to women's rights and they associated gender ideology 
solely with: transgender, transsexual, gay, and they displayed a degree of prejudice against diversity of sexuality and sexual orientation. When told that the gender agenda derives from feminist fight for women's rights, they supported the view that a woman's place is at home rearing children and that giving women choice, particularly in terms of fertility has a negative impact on the future of western societies. Some gave examples of gay couples bringing up adopted children, some of people choosing what sex they would like to be as a matter of whim and finally abortion came into the conversation, associating gender studies with what they felt was immoral and against nature. Even the respondents with higher education occasionally displayed similar opinions, which showed the strength of the faith-tainted message and the influence of the anti-gender campaign on the average citizen. More than half of the interviewed parents were worried about the school curriculum, which in their opinion encouraged "too much lenience" and tolerance towards gender issues (that they felt were inappropriate). Many respondents, even if they did not have small children or children at all were also alarmed by the renown case of the experiment in a private Warsaw nursery, where two carers encouraged toddlers to cross dress on regular basis and tried to engage children in games that trained them in roles that in the parents' view were against the natural gender role division. Thus boys were encouraged to change nappies, wear high heels or cook and girls were encouraged to drill, saw, put fires out, fix cars etc. Even academics in fellow disciplines and university students displayed a degree of disorientation on why there is such an interest in gender, what the Church means and why the gender debate became a dominating subject of private conversations. People were interested to gain more information on what gender is and even when explained the full complexity of the term and the background of gender studies, they would still believe that so called "gender ideology" exists and that it is harmful to children and poses a considerable threat to societal order. All in all the discourse caused moral panic and ill-sentiments towards minority groups amongst many of the interviewees. It also triggered respondents to question social development, human rights and particularly the role and status of women in modern society (apart from academics and university students, who were significantly more pro-diversity). Despite this small scale research results, a recent opinion poll for a daily paper: Dziennik Gazeta Prawna, showed that the gender agenda, and in particular the issue of equality, was not a key priority for an average citizen in Poland. Only 15 percent of respondents in the high earners group, mentioned gender parity as an important issue. The remaining respondents in different status groups did not pay attention to this issue, focusing on the national health service, unemployment and insufficient opportunities for young graduates (Osiecki \& Żółciak, 2014).

\section{Conclusion}

The case study presented, demonstrates that the RC Church in Poland still holds a strong influence on forming public opinion, despite the gradual secularization of the country. In author's opinion, the dynamics of the discourse on gender, both in the Church and the media and its reception by the general public have brought bigotry and intolerance into light. However, it has opened a debate and has raised awareness of the importance of gender issues, gender studies and the existing social barriers to gender based social cohesion and open-mindedness. In opposition to academics, the general public's view in Poland is that "gender ideology" exists, it is atheist and therefore anti-religious.

\section{References}

Acker, J. (1992). Gendered Institutions. From Sex Roles to Gendered Institutions. Contemporary Sociology, 21, 565-569. http://dx.doi.org/10.2307/2075528

Aune, K., Sharma, S., \& Vincett, G. (2008). Women and Religion in the West: Challenging Secularization. Aldershot: Ashgate.

Badran, M. (2009). Feminism in Islam: Secular and Religious Convergences. Oxford: Oneworld Publications.

Baliszewski, T. (2014). Ks. Dariusz Oko mówił w Sejmie o gender. “Ateiści, maniacy seksualni”. http://natemat.pl/89587,ks-dariusz-oko-mowil-w-sejmie-o-gender-ateisci-maniacy-seksualni

Bohdanowicz, A. (2014). Beata Kempa wyruszyła w Polskę ostrzegać przed “ideologia gender”. http://natemat.pl/90069,beata-kempa-wyruszyla-w-polske-ostrzegac-przedideologia-gender

Butler, J. (1993). Bodies That Matter: On the Discursive Limits of “Sex”. New York: Routledge.

Connell, R. W. (1987). Gender and Power: Society, the Person and Sexual Politics. Cambridge: Polity Press.

Daggers, J. (2002). The British Christian Women's Movement. Aldershot: Ashgate.

de Beauvoir, S. (1972 [1949]). The Second Sex. Harmondsworth: Penguin. 
Ekai.pl (2014). Gender oczami specjalistow-Konferencja w Warszawie.

http://ekai.pl/wydarzenia/temat_dnia/x74793/gender-oczami-specjalistow-konferencja-w-warszawie/

Fausto-Sterling, A. (1992). Myths of Gender: Biological Theories about Women and Men. New York: Basic Books.

Fausto-Sterling, A. (2000). Sexing the Body: Gender Politics and the Construction of Sexuality. New York: Basic Books.

Fedele, A. (2012). Looking for Mary Magdalene: Alternative Pilgrimage and Ritual Creativity at Catholic Shrines in France. Oxford Ritual Studies, Oxford: Oxford University Press. http://dx.doi.org/10.1093/acprof:oso/9780199898404.001.0001

Fedele, A., \& Knibbe, K. (2013). Gender and Power in Contemporary Spirituality. London: Routledge.

Gazeta Wyborcza (2014). Minister nauki o gender: "Szanujemy wolność badań i pracy naukowej”. http://wyborcza.pl/1,75478,15270797,Minister_nauki_o_gender_Szanujemy_wolnosc_badan.html\#ixzz32oanurx7

Grzelinska, A. (2014). Gender w przedszkolu? Przebrali chłopca za dziewczynke. http://www.gazetawroclawska.pl/artykul/1084544,gender-w-przedszkolu-przebrali-chlopca-za-dziewczynke,id,t.html?coo $\underline{\mathrm{kie}=1}$

Gumowska, A. (2014). Antygenderowy kurs pod przywództwem księdza Oko. http://polska.newsweek.pl/gender-ukryta-prawda-kurs-dla-katolikow-na-ktory-wybral-sie-newsweek,artykuly,287329,1.ht ml

Harrison, W. C. (2006). The Shadow and the Substance: The Sex/Gender Debate. In K. Davis, M. Evans, \& J. Lorber (Eds.), Handbook of Gender and Women's Studies (pp. 35-52). London: Sage Publication.

http://dx.doi.org/10.4135/9781848608023.n3

Ingersoll, J. (2003). Evangelical Christian Women: War Stories in the Gender Battles. New York: New York University Press.

Jędrzejczyk, M. (2014). Gender grozniejsze od Marksizmu. http://www.naszdziennik.pl/wiara-kosciol-w-polsce/24344

Kessler, S. (1998). Lessons from the Intersexed. New Brunswick, NJ: Rutgers University Press.

Kessler, S., \& McKenna, W. (1978). Gender: An Ethnomethodological Approach. Chicago, IL: University of Chicago Press.

Klassen, C. (2009). Feminist Spirituality: The Next Generation. Lanham, MD: Lexington Books.

Kolarska-Bobińska, L. (2014). Stanowisko MNiSW w sprawie zajęć i badań dotyczacych gender na uczelniach. http://www.nauka.gov.pl/aktualnosci-ministerstwo/stanowisko-mnisw-w-sprawie-zajec-i-badan-dotyczacych-gender-na-u czelniach.html

Kraskowska, E. et al. (2013). List Interdyscyplinarnego Centrum Badań Płci Kulturowej i Tożsamości UAM do Ministry Agnieszki Kozłowskiej-Rajewicz o naruszeniu naszych praw i godności osobistej.

http://studiagender.wordpress.com/2013/12/07/list-interdyscyplinarnego-centrum-badan-plci-kulturowej-i-tozsamosci-uam -do-ministry-agnieszki-kozlowskiej-rajewicz-o-naruszeniu-naszych-praw-i-godnosci-osobistej/

Laqueur, T. (1990). Making Sex: Body and Gender from the Greeks to Freud. Cambridge, MA: Harvard University Press.

Lorber, J. (1994). Paradoxes of Gender. New Haven, CT: Yale University Press.

Luxmoore, J. (2014). Polish Church Declares War on Gender Ideology-A Pastoral Letter by Polish Bishops Has Caused Backlash from Some Who See Attack as a Witch Hunt.

https://www.osv.com/OSVNewsweekly/Article/TabId/535/ArtMID/13567/ArticleID/13990/Polish-Church-declares-war-o n-gender-ideology.aspx

Mantovani, C. (2013). The Truth of Human Love and Gender Ideology in a Document of the Spanish Bishops. http://www.vanthuanobservatory.org/notizie-dsc/notizia-dsc.php?lang=en\&id=1600

McGinty, A. M. (2006). Becoming Muslim: Western Women's Conversions to Islam. New York: Palgrave Macmillan. http://dx.doi.org/10.1057/9780312376215

McGinty, A. M. (2007). Formation of Alternative Femininities through Islam: Feminist Approaches among Muslim Converts in Sweden. Women's Studies International Forum, 30, 474-485. http://dx.doi.org/10.1016/j.wsif.2007.09.004

McGinty, A. M. (2012). Faith Drives Me to Be an Activist: Me to Be an Activist: Two American Muslim Women on Faith, Outreach, and Gender. The Muslim World, 102, 371-389. http://dx.doi.org/10.1111/j.1478-1913.2012.01400.x

Money, J. (1965). Psychosexual Differentiation. In J. Money (Ed.), Sex Research: New Developments (pp. 3-23). New York: Holt, Rhinehart and Winston.

Newsweek (2014). Abp. Michalik nie odpowie za słowa o "ideologii gender" i "agresywnych feministkach". http://polska.newsweek.pl/abp-michalik-gender-feministki-newsweek-pl,artykuly,279284,1.html

Newsweek Polska (2014). Posłowie zorganizowali się przeciwko “ideologii gender”. http://polska.newsweek.pl/paramentarny-zespol-stop-ideologii-gender-beata-kempa-newsweek-pl,artykuly,278384,1.html 
Oakley, A. (1972). Sex, Gender and Society. London: Temple Smith.

Osiecki, G., \& Żółciak, T. (2014). Sondaż DGP: Chcemy państwa opiekuńczego. Nie gender. http://www.gazetaprawna.pl/artykuly/800648,sondaz-dgp-chcemy-panstwa-opiekunczego-nie-gender.html

PAP (2014). Leszek Miller: Gender to nauka, nie ideologia. http://wiadomosci.wp.pl/kat,1025897,title,Leszek-Miller-gender-to-nauka-nie-ideologia,wid,16358798,wiadomosc.html?ti caid=112cb5

Pawlicka, A. (2014). Beata Kempa i spółka, czyli młot na gender. http://polska.newsweek.pl/stop-ideologii-gender-i-beata-kempa-na-newsweek-pl,artykuly,279041,1.html

Petrowa-Wasilewicz, A., \& Przeciszewski, M. (2013). Dlaczego Kosciół mowi o gender? http://ekai.pl/wydarzenia/temat_dnia/x73681/dlaczego-kosciol-mowi-o-gender/

Podgórska, J. (2014). Gender i pedofilia. http://www.polityka.pl/tygodnikpolityka/kraj/1564277,1,kosciol-walczy-z-nowym-wrogiem.read

Polityka (2014). O dzieciach dla dorostych. http://www.polityka.pl/tygodnikpolityka/kraj/1566673,1,podstepny-gender-czyha-na-przedszkolaki.read

Polskie Radio (2014). Biskupi o gender. "Ma charakter destrukcyjny wobec człowieka”. http://www.polskieradio.pl/5/3/Artykul/1012461,Biskupi-o-gender-Ma-charakter-destrukcyjny-wobec-czlowieka

Radomski, J. (2014). Nauka Gender vs. Ideologia Jesus. http://www.tokfm.pl/blogi/liberte/2014/01/jan_radomski_nauka_gender_vs_ideologia_jesus/1

Redzioch, W. (2014). Gender-nowa, niebezpieczna ideologia. http://www.niedziela.pl/artykul/78160/nd/\%E2\%80\%9EGender\%E280\%9D--nowa-niebezpieczna

Regnerus, M. (2012). How Different Are the Adult Children of Parents Who Have Same-Sex Relationships? Findings from the New Family Structures Study. Social Science Research, 41, 752-770. http://dx.doi.org/10.1016/j.ssresearch.2012.03.009

Rogojsz, L. (2014). Gender, czyli dziewczynka do bicia. http://polska.newsweek.pl/gender-kontrowersje-spory-gender-studies-zalozenia-studia-genderowe-plec-kulturowa-newswe ek-pl,artykuly,278337,1.html

Ryś, M. (2013). Co ma kosciót do gender. http://www.idziemy.com.pl/spoleczenstwo/co-ma-kosciol-do-gender/3/

Ryś, M. (2014). Gender a prawa reprodukcyjne. http://www.fronda.pl/a/gender-a-prawa-reprodukcyjne,33892.html

Rzewuski, P. (2013). Gender: Między ideologia a nauka, czyli co to właściwie jest. http://histmag.org/8845

Stoller, R. (1968). Sex and Gender: On the Development of Masculinity and Femininity. London: Hogarth Press.

Tutak-Goll, M. (2013). Barbara Limanowska: Co to jest gender. http://www.wysokieobcasy.pl/wysokieobcasy/1,98083,15194525,Barbara_Limanowska_Co_to_jest_gender.html

Wiara.pl (2014a). Biskupi o gender-List pasterski. http://papiez.wiara.pl/doc/1827010.Biskupi-o-gender-list-pasterski

Wiara.pl (2014b). Dlaczego gender jest tak niebezpieczne. http://info.wiara.pl/doc/1403501.Dlaczego-gender-jest-tak-niebezpieczne

Wpolityce.pl (2014). O gender w Episkopacie-Czy to dobre miejsce na tego typu dyskusję? http://wpolityce.pl/polityka/183869-o-gender-w-episkopacie-czy-to-dobre-miejsce-na-tego-typu-dyskusje

Youtube (2014). O co chodzi w gender? Abp Marek Jędraszewski. http://www.youtube.com/watch?v=3ESROktnEB8

Zwissler, L. (2007). Spiritual, but Religious. Culture and Religion, 8, 51-69. http://dx.doi.org/10.1080/14755610601157120 
Scientific Research Publishing (SCIRP) is one of the largest Open Access journal publishers. It is currently publishing more than 200 open access, online, peer-reviewed journals covering a wide range of academic disciplines. SCIRP serves the worldwide academic communities and contributes to the progress and application of science with its publication.

Other selected journals from SCIRP are listed as below. Submit your manuscript to us via either submit@scirp.org or Online Submission Portal.
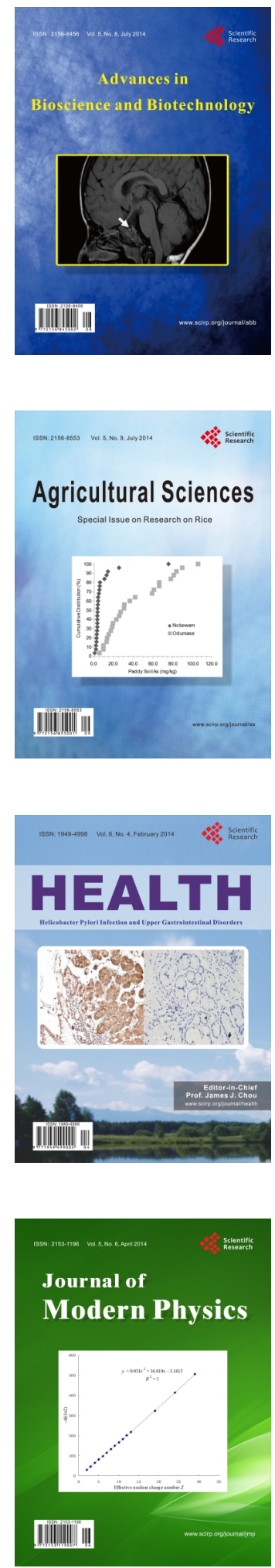
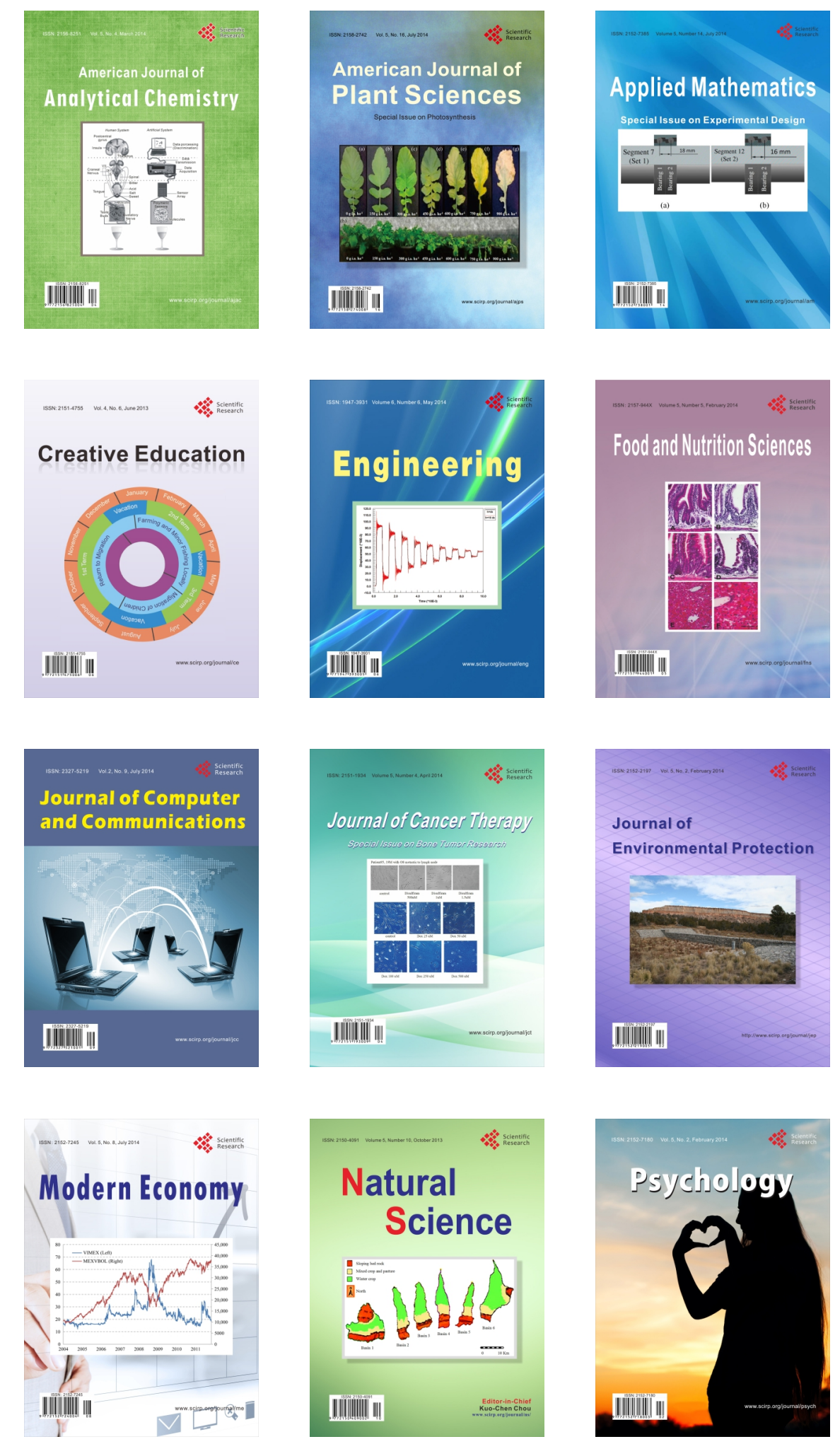